\title{
NARRATIVAS DO TEMPO DA NOITE: A LITERATURA DE TESTEMUNHO EM PEDRO TIERRA
}

\author{
NIGHT TIME NARRATIVES: \\ THE TESTIMONY LITERATURE IN PEDRO TIERRA
}

\author{
Luiza Helena Oliveira da Silva ${ }^{1}$
}

\begin{abstract}
Também já afirmei que invento sim e sem o menor pudor. As histórias são inventadas, mesmo as reais, quando não contadas. Entre o acontecimento e a narração do fato, há um espaço de profundidade, é ali que explode a invenção. Nesse sentido venho afirmando: nada que é narrado em Becos da memória é verdade, nada que está narrado em Becos da memória é mentira. Ali busquei escrever a ficção como se estivesse escrevendo a realidade vivida, a verdade.
\end{abstract}

Conceição Evaristo, Becos da memória.

\begin{abstract}
RESUMO: Este artigo analisa o livro de contos Pesadelo: narrativas dos anos de chumbo, de Pedro Tierra (2019). Inscrevendo-o na categoria da literatura de testemunho, partimos de seus textos para pensar a produção do sentido em torno do acontecimento, considerando sua apreensão pelos estudos da semiótica tensiva. Ao acontecimento reunimos a resistência do campo literário que se faz pela memória e pela denúncia do presente vivido como contínuo, a precarizar a emergência do sentido.
\end{abstract}

PALAVRAS-CHAVE: Literatura de Testemunho; Pedro Tierra; Semiótica Discursiva; memória, resistência

ABSTRACT: This paper analyses the tale's book Pesadelo: narrativas dos anos de chumbo, by Pedro Tierra (2019). Through inscribing it in the category of literature of testimony, we start from his texts to think about the production of meaning around the event, considering the apprehension of it by the studies of tensive semiotics. To the event we assemble the resistance of the literature field that happens by the memory and the arraignment of the lived present as a continuum that precarizes the emergence of the meaning.

KEYWORDS: Testimonial Literature; Pedro Tierra; Discursive Semiotics; memory; resistance

\section{Introdução}

Neste artigo, propomos uma análise do livro Pesadelo: narrativa dos anos de chumbo, de Pedro Tierra (2019) considerando-o como literatura de testemunho. Como tal, emergem quase sempre inicialmente diante de produções dessa natureza inquietações quanto à relação entre a literatura e o real da experiência. Principiamos pela citação de Evaristo porque ela sinaliza bem as fronteiras atravessadas pela narrativa, os espaços de que se ocupa um certo tipo

\footnotetext{
${ }^{1}$ Doutora em Letras pela UFF. Professora da UFT e docente no PROFLETRAS e no PPG em Letras: Ensino de Língua e Literatura. Coordena o GESTO (Grupo de Estudos do Sentido - Tocantins). Pesquisa com apoio CAPES; Grupo de Estudos do Sentido - Tocantins (GESTO).
} 
de produção, entre invenção/ficção/imaginação e a vivência do acontecimento, sem a ilusória busca da perspectiva de tradição positivista que opera para distinguir o que se vai pôr na categorização do fato e o que se vai colocar na conta da literatura, como se fosse possível narrar qualquer vivência sem a inscrição ali de um sujeito que rearranja o vivido sob um ângulo particular, ficcionalizando, pois, o real experimentado. Além disso, conforme Seligmann-Silva, não se pode pensar ao mesmo tempo sob uma visão positivista da história: "ao invés da representação, tem-se apresentação: o objeto de relato é construído num determinado presente do escritor" (SELIGMANN-SILVA, 1998, p. 21), o que implica, necessariamente, no caso desse tipo de produção um dado engajamento do enunciador que vai conformar uma "nova ética de representação que despreza a indiferença política" (SELIGMANN-SILVA, 1998, p. 22).

Nessa direção, encontramos uma "advertência" na introdução de Pesadelo... Anunciando ao leitor as características de sua narrativa, Tierra alerta para a comunhão das duas forças que mobiliza para tecer, enquanto denuncia a circularidade da nossa história, sempre com frágeis períodos de intervalo democrático, a obrigar que se narre também como "premonição":

O círculo perfeito: as tiranias no Brasil, ora nos perseguem, ora se anunciam. Ora vestem fardas, ora envergam togas. Ainda não conseguimos contar e sepultar os mortos daquela que anoiteceu o país por 21 anos e seus herdeiros já arrombam nossa porta. De tal modo que não estou seguro sobre se as narrativas que lhes ofereço nestas páginas serão relatos do já vivido ou premonições sobre o destino que nos aguarda. Trata-se de textos urdidos pela imaginação. Narrativas de lutas, traições, culpas. De vidas e mortes. Num país onde a história se tece com os fios da própria ficção, pode ser que algum leitor as tome como verdade. (TIERRA, 2019, p. 11)

Como literatura de testemunho, não temos a pretensa indiferença das opções estéticas que prescrevem a "arte pela arte". O enunciador assume expressamente sua posição frente aos acontecimentos narrados, narrando-os expressamente como denúncia e crítica à violência e ao abuso:

[...] o estudo do testemunho articula estética e ética como campos indissociáveis de pensamento. O problema do valor, da relevância da escrita, não se insere em um campo de autonomia da arte mas é lançado no âmbito abrangente da discussão de direitos civis, em que a escrita é vista como enunciação posicionada em um campo marcado por conflitos, em que a imagem da alteridade pode ser constantemente colocada em questão. (GUINZBURG, 2011, s/p).

Ainda citando Guinzburg (2011), essa literatura na qual se inscreve a produção de Tierra afasta-se dos discursos hegemônicos vinculados aos ideários nacionalistas, na medida em que atribui voz a sujeitos subalternos e excluídos, a discursos silenciados ou esquecidos, rompendo e fraturando a concepção fixa e unitária da narrativa histórica. Trata-se, portanto, de uma 
literatura implicada, comprometida com uma perspectiva sobre a realidade, expressamente vinculada à ordem da subjetividade e ao sensível.

Conforme já anunciava Primo Levi (1988), testemunha-se o vivido para denunciar sua crueza, sua violência, para aqueles que não o viveram mas precisam ter disso notícia, para que se não volte a repetir, porque muitos daqueles que sofreram seus efeitos já não podem narrar por estarem mortos e, sem narrar, não se produz sentido, nem memória, nem capacidade de resistir e operar transformações. Narrar é, então, uma imposição, na luta contra o esquecimento ou a negação, como já anuncia Primo Levi, no prefácio de É isto um homem?: "A necessidade de contar 'aos outros', de tornar 'os outros' participantes, alcançou entre nós, antes e depois da libertação, caráter de impulso imediato e violento, até o ponto de competir com outras necessidades elementares" (LEVI, 1988, p. 7-8).

Como é sabido, Levi narra, logo após o fim da guerra quando deixa o campo de concentração de Auschwitz, os horrores a que judeus, comunistas, homossexuais e ciganos foram submetidos durante a sanha genocida dos nazistas. Precisa contar porque milhões já não podem, assassinados pela máquina hitlerista que impôs sua "solução final", visando ao extermínio. No caso de Tierra, retomar as memórias da ditadura se faz urgência quando entram em cena atores que atualizam os discursos que levaram ao golpe em 1964 e se anunciam novamente ferozes a partir da própria negação do passado, num revisionismo histórico que serve ao fascismo sob roupagem ultraliberal.

Esse enunciador implicado assume mover-se pela urgência de narrar o vivido, assumindo simultaneamente a insuficiência da linguagem para dar conta da dimensão da experiência. Como "sobrevivente" de um acontecimento absurdo, o enunciador toma para si esse dever de contar, après-coup, indo além do espanto, na medida em que, no instante em que a coisa acontece, pouco há além da surpresa que destitui o sujeito da capacidade de dar sentido pela linguagem (ZILBERBERG, 2011; GREIMAS, 2002; SILVA, 2016): "Sobrevivi à partida de xadrez, contra a morte. Sobrevivi, talvez, para contar essas coisas presas nas armadilhas da memória" (TIERRA, 2019, p. 65). O enunciador se move então entre a necessidade de dizer e a precariedade da linguagem, mesmo colocado já a uma "boa distância", na condição de sujeito da memória, a analisar os efeitos e as consequências.

Nos anos da ditatura civil militar no Brasil (1964-1985), Tierra, pseudônimo de Hamilton Pereira da Silva (Porto Nacional/TO, 1948 -), fez parte do grupo de resistência denominado Aliança Libertadora Nacional (ALN), enfrentando a prisão e tortura entre 1972 e 1977. Seus primeiros poemas são escritos durante esse período, encaminhados clandestinamente para a Itália, onde são impressos sob o título Poemas do povo da noite (2009 
[1977]). O livro recebe o prêmio Casa de las Américas (1978), tendo sua publicação no Brasil apenas em 1979. Posteriormente, publicou Missa da Terra sem males, com Pedro Casaldáliga e Martin Coplas (1979), Missa dos Quilombos, com Pedro Casaldáliga e Milton Nascimento (1981), Água de Rebelião (1983), Inventar o Fogo (1986), A palavra contra o muro (2013), os livros dedicados ao público infantil Passarinhar (1992) e Bernardo Sayão e o Caminho das onças (1997). Em 2019, escreve o primeiro livro de ficção em prosa, Pesadelo: narrativas dos anos de chumbo (2019), que remete a sua experiência como militante político no período ditatorial brasileiro. Em entrevista concedida em 2018, Tierra fala a respeito dessa produção:

Concluí nos últimos dias de 2018 um pequeno livro. Como é o mais recente por algum tempo será o mais importante... Pela primeira vez ficção em prosa. Uma experiência árdua. Imaginei produzi-lo em um ano. Levei três para concluir. São seis histórias curtas e levará por título "O pesadelo circular (Narrativas dos anos de chumbo)". Histórias imaginadas num país que anda em círculos... Uma experiência como essa me põe à prova. Como me afastar da linguagem poética que molda minha produção há tantos anos para me aproximar de um relato mais 'objetivo'? É um exercício de aprendizado e não estou muito seguro se alcancei o resultado desejado. O leitor dirá. Como nos livros anteriores, não posso abrir mão de recorrer à memória e à invenção, afinal, parafraseando Manoel de Barros: "Tudo que não invento, é falso..." (TESTA; MARINHO, 2018, p. 369)

Como ressalta em sua fala, antecipando o livro a ser então publicado, Tierra analisa a circularidade dos acontecimentos políticos no país, salientando as aproximações entre a ditadura pós-1964 e os fatos que levaram ao golpe contra Dilma Rousseff (2015-2016). Para o autor, o livro foi escrito simultaneamente mediante a memória e uma espécie de "premonição" quanto ao desenrolar dos fatos no cenário nacional. Tal premonição é, então, possível justamente em função da memória. É por trazer a memória do vivido que se torna possível ler os indícios no presente e antecipar o que está por vir e, na medida do possível, agir como sujeito para alterar o rumo de uma dada programação que repete a história como farsa.

Para além dos limites do projeto identitário que parece engajar alguns dos escritores prestigiados no Tocantins, Tierra não se circunscreve ao regionalismo, voltando-se para temáticas de interesse mais amplo, ainda que, a seu ver, possam ser menos palatáveis dada a orientação política e ideológica de suas escolhas.

Em função de sua militância político-poética, não deixa de lado a urgência da escrita no “calor da hora", preconizando o poder da práxis poética de natureza libertária. Ao mesmo tempo, assume que poesia se escreve com palavras, não com sentimentos, o que explicita o cuidado com a dimensão estética e a rejeição ao panfletário. Interessa-nos essa enunciação singular que (re)constrói a memória do vivido, trazendo nuances para a compreensão de processos históricos e o modo como a literatura se inscreve nas dinâmicas que disputam 
sentidos para a história do país. Tal enunciação se inscreve no corpo sensível, atravessada pela intensidade afetante da memória: "Essa ética e estética da literatura de testemunho possui o corpo - a dor - como um de seus alicerces" (SELIGMANN-SILVA, 1998, p. 22). Neste artigo, a partir dos estudos em torno da literatura do testemunho e de categorias da semiótica discursiva, propomos uma análise da prosa de testemunho de Tierra (2019), intentando levantar questões que visam a trazer contribuições para compreensão do que se faz nesse gênero literário no país.

\section{Breves apontamentos sobre o gênero literatura de testemunho}

Conforme Marco, o gênero literatura de testemunho não se confunde com a noção de uma produção literária que testemunha seu tempo, o que abarcaria numa generalidade toda a literatura. $\mathrm{O}$ que a caracteriza primordialmente é que "remete sempre a uma relação entre literatura e violência" (MARCO, 2004, p. 45). Sob essa perspectiva, pensamos esse gênero a partir de uma primeira oposição, que permite que abriguemos não apenas os textos que se inscrevem na ordem do acontecimento, como os relatos relativos à Shoah judaica ${ }^{2}$, mas os que remetem também à esfera do contínuo, de uma regularidade, como a da violência que se naturaliza e que a literatura desnaturaliza ao assumir o tom da denúncia. O relato testemunhal tomado como objeto pelo literário vai, assim, ora traduzir o horror de uma situação excepcional, como se dá frente a emergência dos grandes genocídios, ora buscar imprimir tonicidade ao que, por se encontrar na esfera do cotidiano, do sempre o mesmo, do estável, já não parece afetar os sujeitos, apáticos na condição de não poder sentir, anestesiados.

Nesse segundo caso, estaria inserida Carolina Maria de Jesus, com Quarto de despejo: diário de uma favelada, por exemplo (JESUS, 2014). Não se trata ali de uma ruptura com um estado de coisas, uma súbita mudança que aturde os sujeitos, caracterizando o acontecimento, mas de um cotidiano que é ignorado e do qual a escritora será porta-voz para fazer ver o que parece invisível no cenário da metrópole.

O mesmo pode ser pensado a partir da produção recente do jornalista José Roberto Torero Fernandes Junior com suas duas séries em torno da pandemia do Covid-19, Quarentena e Quarenteninhas, que publica no Facebook. A pandemia é, sem dúvida, sentida como acontecimento, que nos aturde neste momento e que sinaliza para a dificuldade de compreensão dada a intensidade com que a percebemos a modificar drasticamente nossa vida, em função dos milhares de mortes de pessoas cada vez mais próximas, por não visualizarmos ainda seu

\footnotetext{
${ }^{2}$ Compreendida como a literatura do trauma judaico na II Guerra Mundial (FIGUEIREDO, 2020).
} 
desfecho, adensada por uma duração intensamente sentida em sentido ascendente. Escrevemos neste instante como os judeus que registravam seu terror no gueto de Varsóvia, sem saber se sobreviveremos. Se o extermínio é da ordem do acontecimento, tanto quanto a pandemia, nessas séries, porém, encontramos ainda o que se constitui no contínuo, como o do da morte do menino João Pedro, assassinado em sua casa pela polícia no Rio de Janeiro. Publicado em 22 de maio de 2020 (https://www.facebook.com/joserobertotorero), a crônica pode ser lida como narrativa do acontecimento dentro do acontecimento, mas que denuncia o genocídio da população negra no Brasil, regularidade silenciada e invisibilizada.

Frente à atonia e à anestesia produzidas pela regularidade com que se matam negros nas periferias do país, Torero subtrai a história do menino, buscando conferir intensidade para uma vida em particular. Inserida na proposta de crônicas para crianças, Quarenteninhas 3 explicita o afastamento de dois universos que não dialogam: o do menino que brinca com urso de pelúcia ao lado do pai e que se abriga da pandemia em casa como proteção; o do menino João Pedro, cuja casa não pôde protegê-lo da ação do Estado. Para não romper com o estado de coisas, o pai interrompe as indagações da criança, mudando o canal de TV para que o filho encontre temática menos incômoda. A morte de uma criança não altera, pois, a vida, que segue sua "boa" programação, perpetuando a morte de muitos cujos nomes não serão objeto de grande atenção. A violência no Brasil não é acontecimento, mas o que se espera, dada uma conjunção de fatores socioeconômicos que não se altera. Do ponto de vista da compreensão da literatura de testemunho, há, portanto, a que trata do acontecimento, mas também a que emerge como resistência à atonia da programação.

\subsection{Ainda em torno do acontecimento}

O acontecimento tem um lugar de centralidade na gramática tensiva desenvolvida por Zilberberg (2011). Pressupõe que algo advém e, como tal, entra inesperadamente no campo de presença do sujeito aturdindo-o, pondo-o momentaneamente sob efeito de uma súbita precipitação. Esse "sujeito do estupor" que então emerge, esse "sujeito do espanto" (ZILBERBERG, 2011, p. 25) e que demora a voltar a si, disjunge-se daquele que o sucede, quando a intensidade da vivência do acontecimento caminha em direção à atenuação e é de novo, capaz de retomar o controle, as condições para saber e poder dizer, constituindo-se como sujeito da retórica.

Caracteriza o acontecimento a subtaneidade de uma aparição, que é sentida como tal na medida em que encerra a noção de ruptura com um dado estado de coisas, com uma duração intensamente sentida, mas breve, mas cujas consequências perduram como ainda afetantes, 
permanecendo como tal no plano da memória. Conforme Fontanille, ao discorrer sobre o acontecimento histórico,

[...] é necessário primeiramente localizar um conjunto de fatos adjacentes e subsequentes que atestem a força transformadora daquilo que "ocorreu", o que estimulará eventualmente, como contrapartida, uma investigação das "causas" que, se tivessem sido identificadas previamente, teriam permitido antever o acontecimento. A programação, se ela existe, não é, portanto, reconstruída senão a partir das consequências, o que é um atestado da imprevisão e da ocultação, no momento mesmo em que o acontecimento apreende o observador. (FONTANILLE, 2016, p. 36)

É, portanto, apenas após a vivência do acontecimento que é possível avaliar as condições que o precederam e intuir sobre suas causas. Uma possível depreensão de uma programação que o teria gerado, resultante de uma implicação entre as fatos e coisas, só pode ser construída a posteriori, porque é da natureza do acontecimento a impossibilidade de sua antecipação, dada sua natureza concessiva. Se, no auge da experiência, o sujeito encontra-se em estado de estupor e se não podia ser capaz de antever o que adveio, o acontecimento só pode ser lido, então, como memória, no movimento descendente da atenuação:

\begin{abstract}
O acontecimento não pode ser apreendido senão como algo afetante, perturbador, que suspende momentaneamente o curso do tempo. Mas nada nem ninguém conseguiria impedir que o tempo logo retome seu curso e que o acontecimento entre pouco a pouco nas vias da potencialização, isto é, primeiramente na memória, depois, com o tempo, na história, de maneira que, grosso modo, tal acontecimento ganhe em legibilidade, em inteligibilidade, o que perde paulatinamente de sua agudeza. (ZILBERBERG, 2011, p. 169)
\end{abstract}

Para lembrar, contudo, é necessário que o que adveio guarde algo da potência da sua intensidade, que não se esvaneça rumo à vacuidade (SILVA, 2016). É essa intensidade que parece ser reavivada pela figuratividade explosiva de Tierra, ao retomar as cenas da prisão e da tortura, ao mesmo tempo em que parece buscar compreender os processos que ali tiveram lugar. A inteligibilidade se alia então à dimensão do afeto e a paixão, relativa à instância do sofrer, tem de novo seu lugar, reavivando pela potência do texto o que adveio. É da tarefa do testemunho buscar, ainda que em vão, as palavras capazes de também inflamar o leitor, como discorre Coquio (2003) ao comentar o texto de Zalman Gradowski, escrito em Auschwitz:

\begin{abstract}
Mais il se sait surtout anormalement confronté à la représentation de sa situation de lecture, en même temps qu'à la situation d'exception de l'écrivain. Il se prend, face à ces lignes enflammées, à imaginer le témoignage ou le poème idéal : imagination impossible, non du fait des limites de la littérature, mais parce que la position de témoin — le rapport du « sujet » à la « situation » — est impartageable et même trop pénible à imaginer ${ }^{3}$. (COQUIO, 2003, p. 362)
\end{abstract}

\footnotetext{
${ }^{3}$ Em tradução livre: "Mas sabe, especialmente que é confrontado de modo anormal com a representação de sua situação de leitura, ao mesmo tempo que com a situação excepcional do escritor. Frente a essas linhas inflamadas, ele se põe a imaginar o testemunho ou o poema ideal: imaginação impossível, não em função dos limites da literatura, mas porque a posição de testemunha - a relação do "sujeito" com a "situação" - não é compartilhável e mesmo penosa demais para se imaginar".
} 
No caso de Gradowski, a situação da escrita é ainda mais penosa, porque se faz durante o próprio acontecimento, dada a possibilidade, tal como se deu, de que não existisse um amanhã. Tal como ele, Tierra também produz no cativeiro, acolhendo então a poesia como forma de manifestação (2009). O cuidado conferido à forma, o trabalho poético que teme o efeito panfletário, permitem romper o atordoamento, resistir ao caos que se impõe como norma, frente ao não saber, ao imprevisível num processo que, conforme Coquio, remetendo a explicações de Borwicz, busca, "d'une part, « compenser » le violent « déclassement » vécu, d'autre part, conduire un processus de « clarification » propice à la survie"4 (COQUIO, 2003, p. 354). Assim, ainda que sob torpor, o sujeito é capaz de resistir na linguagem: "Sou o poeta dos torturados, /dos 'desaparecidos'/ dos atirados ao mar, /sou os olhos atentos/sobre o crime" (TIERRA, 2009, p. 30).

Para os que narram como sobreviventes, a memória revela a permanência da intensidade do acontecimento, ainda que não com a mesma contundência, porque a direção se faz agora rumo à descendência (ZILBERBERG, 2011). Mas o que resta para o que sobrevive? Tierra fala da duração afetante que leva sujeitos a diferentes estados après coup.

No primeiro conto, Sinfonia $n^{o}$ 2, por exemplo, caracterizando a continuidade dos efeitos, o personagem não pode esquecer, assombrado pela memória da tortura que se repetia ao som insistente da sinfonia de Sibelius ${ }^{5}$ : "Horas sobre horas, noites sobre noites: até imprimir os acordes na medula da alma" (TIERRA, 2019, p. 35). O tempo passa, como se pode confirmar pela promoção do ex-torturador e oficial medíocre a coronel, registro da sanção positiva do sistema aos seus feitos, mas o sujeito não pode esquecer, por isso mesmo não é capaz de perdoar. Leva consigo, então, uma corda de violoncelo, objeto que encerra metonimicamente a experiência do cárcere.

O Capitão - já não era Capitão, era Coronel reformado - foi encontrado morto. Com uma corda de violoncelo atada ao pescoço. Não se registrou no cadáver sinais de luta corporal. Se houve, o laudo ocultou. Não foi o único. Entrou para uma relação macabra de mortes inexplicadas: acidentes, suicídios, assassinatos, desparecimentos de homens que serviram aos subterrâneos naqueles anos de muro e medo. (TIERRA, 2019 , p. 46)

\footnotetext{
${ }^{4}$ Em tradução livre: por um lado, ‘compensar' o violento 'desmantelamento' vivido, por outro, conduzir um processo de "esclarecimento" propício à sobrevivência".

${ }^{5}$ Jean Sibelius (1865-1957) foi um compositor finlandês bastante popular nas primeiras décadas do século XX. Em 1935, foi condecorado por Hitler. Em 1942, Goebbels cria uma Sociedade Sibelius da Alemanha. No conto, evidencia-se a aproximação entre a ditadura e o ideário nazista.
} 
A morte inexplicada do coronel deixa para o narrador apenas lacunas frente a um "vasto repertório de respostas" que jamais chegarão a ser enunciadas, como as que vai levantando ao longo do conto sobre o prazer sádico daqueles que, situando-se como meros operadores de uma programação em processo, põem-se a moer o corpo e a alma do outro, cumprindo a tarefa preconizada pela engrenagem, essa mesma que aniquila "seus próprios filhos" (TIERRA, 2019, p. 46), substituíveis peças no tabuleiro de morte.

\subsection{Plurivocidade: vozes que disputam a memória}

Do ponto de vista de seu estatuto genérico, Achúgar define a produção do testemunho na América Latina, testimonio, pela noção de "porosidade", na medida em que não se encerra numa classificação tradicional (conto, novela, memória, autobiografia etc.), nem corresponde à distinção ficcional/não-ficcional, com fronteiras que deixam atravessar, porosas. Acentua ainda que essa porosidade "no implica pastiche ni tampoco multiplicidad de estrategias discursivas o una incertidumbre a nivel referencial, apenas señala una cierta indecisión lógica del estatuto genérico y discursivo del testimonio" (ACHÚGAR, 2002, p. 63) ${ }^{6}$, sem buscar com isso corresponder ao ecletismo das produções literárias contemporâneas. Abrigam tanto as produções que ecoam a luta de um setor, grupo, classe ou comunidade que deseja destituir um dado grupo do poder quanto aquelas que "aspiran al establecimiento por coparticipación de una comunidad plural o heterogénea sin hegemonías absolutas al menos a nivel discursivo ${ }^{7}$ " (ACHÚGAR, 2002, p. 64). No caso de Tierra, trata-se da disputa pela memória do passado recente do país, sobretudo após o impeachment de Dilma Rousseff, quando começa a se fortalecer a negação de que tenha ocorrido uma ditadura no Brasil ou porque passam a concorrer fortemente discursos que a legitimam como prática política, numa temível circularidade que pode trazer de novo o autoritarismo ao poder.

Ainda remetendo a Achúgar (2001), o testemunho ressoa assim como "voz paralela", instaurando-se sob a perspectiva da plurivocidade, da polifonia, desestabilizando a narrativa que se torna ou se tornou oficial, naturalizada pelos grupos do poder.

No texto de Tierra, ecoam essas vozes em confronto, marcadas pela distinção entre a voz do narrador, que fala de si e de suas experiências com outros presos nos vários presídios nos quais esteve encerrado e, pelo recurso do discurso direto, grafado em itálico e entre aspas,

\footnotetext{
${ }^{6}$ Em tradução livre: "não implica pastiche nem tampouco multiplicidade de estratégias discursivas ou uma incerteza em nível referencial, apenas assinalando uma certa indecisão lógica quanto ao estatuto genérico e discursivo do testemunho".

${ }^{7}$ Em tradução livre: "aspiram ao estabelecimento por coparticipação de uma comunidade plural ou heterogênea sem hegemonias absolutas ao menos no nível discursivo".
} 
as vozes dos torturadores e das outras vítimas, cruzando as diferentes perspectivas e sentidos em disputa.

No conto Coragem, por exemplo, a voz que ressoa o discurso da ditadura ecoa na fala do Cabo Torrezan, em seu "um metro e noventa de estupidez", repetindo em sua ronda a cantilena que fazia os prisioneiros inimigos do país: "Vocês não são brasileiros! Perderam a cidadania! São apátridas! Vocês são o veneno da nação! São os comunistas! Comunistas não têm pátria! Quando saírem daqui não terão nem direito ao túmulo. Irão direto pros infernos, sem deixar rastros!"' (TIERRA, 2019, p. 91). A resposta vem no murmúrio da canção de Geraldo Vandré, que se tornou uma espécie de hino da resistência naquele período, como, mais adiante, na voz de um dos prisioneiros, em torno de sessenta anos, dirigente do PCB, leitor de Thomas Mann, que também é citado no exercício polifônico. Frente à proposta de um general que assoma à cela - “Quem de vocês aceita ir para a televisão e se declarar arrependido?” - responde o velho dirigente:

\footnotetext{
"General, a cela é o espaço do preso. O último espaço. O senhor, portanto, não devia ter entrado aqui. $\mathrm{O}$ senhor vir aqui oferecer a esses meninos que se arrependam em troca de qualquer coisa eu compreendo, embora não aceite. O senhor fazer essa proposta para mim, um comunista moído de pancada por suas mãos de ferro, é um insulto! O senhor se retire da cela. Aqui ninguém se arrepende!" (TIERRA, 2019, p. 99).
}

Além dessa clara oposição que marca a filiação ideológica dos locutores colocados em situações distintas em função de seu papel temático (preso/torturador), há ainda a própria complexidade dos discursos da esquerda, expressamente heterogêneos, assim como a distinção que emerge entre as várias gerações de militantes que ali são reunidos, sob a mesma violência. Ali se encontra o velho militante do PCB, em princípio visto com reticência pelo narrador, como se ajuntam jovens que parecem ter sido capturados diretamente de uma sala de aula, repetindo ciosos práticas discursivas da esquerda: "Ouço essa arenga desde que ingressei na esquerda" (TIERRA, 2019, p. 146), no conto Os ossos do rio verde.

Como expressa Tierra, a resistência do velho frente ao coronel traz ânimo ao grupo fragilizado, demonstrando a permanência da coragem mesmo sob condições tão miseráveis, o que os leva a uma vontade de contar aos companheiros o que não havia necessidade de lhes contar dado que todos tinham participado do episódio. A memória que retoma esse momento de maneira especial testemunha mais tarde, portanto, para os que não estiveram lá. Há, afinal, como nas palavras de Gradowski, dois universos que parecem coexistir, impondo-se que aquele 
que viveu no inferno - au coeur de l'enfern - traga para os que não o experimentaram a confirmação de sua existência ${ }^{8}$ :

La lune, il y en a certainement deux. Une pour les peuples, gentille et douce, qui sourit tendrement au monde, qui entend le chant du bonheur et de la joie. Et une, pour notre peuple, une Lune cruelle, brutale, qui se tient là calme et raide, et qui entend les lamentations et les cris des cœurs, des millions, qui se débattent avec elle, la mort, qui marche vers eux ${ }^{9}$. (GRADOWSKI apud COQUIO, 2003, p. 361)

Ao mesmo tempo, há vozes que ainda não foram ouvidas, em função da própria dor, pela continuidade dos efeitos que se encerram sobre o corpo e alma daquele que viveu, pela fratura que permanece cindindo o sujeito. Também porque dizer pode implicar experiências de nova sanção por parte de um Estado que não se fez efetivamente democrático, tendo premiado os algozes, que de novo voltam com força ao comando do país ${ }^{10}$.

\section{Vivendo o pesadelo}

Pesadelo reúne 7 contos, que se subdividem em seções breves. As frases são quase sempre curtas, numa escrita que prima pela clareza, objetividade e concisão, potencializando os efeitos da contundência que imprime como efeito da brevidade, da cuidadosa seleção e combinação de palavras, num estilo possivelmente adquirido pela experiência poética. Aos contos se somam uma entrevista, que serve de introdução ao livro; uma biografia, ao final; notas dos editores nas orelhas; citação, na contracapa, de artigos da Declaração Universal dos Direitos do Homem, documento da Organização das Nações Unidas, de 1948, que coincide com o ano de nascimento de Tierra.

A capa de tom verde escuro (Fig. 1), produzindo forte contraste cromático, traz o título e nome do autor em laranja, tendo como fundo a imagem retocada pelas gradações do verde. Corresponde ao trabalho gráfico que incide sobre a imagem que reencontraremos após os textos da "Advertência" e de "Agradecimentos" (Fig. 2). As quatro gravuras que atravessam o livro são de autoria de Elifas Andreato, essencialmente figurativas, com cenas diversas, em alguns

\footnotetext{
${ }^{8} \mathrm{O}$ texto de Gradowski foi escrito em Auschwitz, encontrado ao final da guerra e reunido por pesquisadores a outras produções do testemunho (Cf. COQUIO, 2003).

${ }^{9}$ Em tradução livre: “A lua, há certamente duas. Uma para o povo, gentil e doce, que sorri ternamente ao mundo, que ouve a canção da felicidade e da alegria. E uma para nossa gente, uma Lua cruel, brutal, que fica lá calma e rígida, e que ouve lamentações e os gritos dos corações de milhões que se debatem com ela, a morte, que caminha em sua direção".

${ }^{10}$ Veja-se a esse respeito o caso do "Major Curió", tenente-coronel da reserva, Sebastião Curió Rodrigues de Moura (1934 - ), recebido com honras no Planalto pelo presidente Bolsonaro, em maio de 2020. Tendo sido um dos mais temíveis agentes da repressão no Araguaia, seguiu como liderança política no Pará, sendo nomeado interventor federal da Serra Leste, que compreendia a área de garimpo de Serra Pelada. Disponível em https://www.correiobraziliense.com.br/app/noticia/politica/2020/05/06/interna_politica,851825/bolsonarorecebe-major-curio-agente-de-repressao-na-ditadura.shtml Acesso em 30 mai 2020.
} 
casos justapostas, que remetem ao cárcere e ações de tortura tematizados pelos contos, acentuando o caráter dramático num realismo naif ${ }^{11}$ das cenas representadas. Na página de rosto, compõem unidas um painel situado entre título e subtítulo. Nelas emergem os corpos atravessados por aparelhos de tortura diversos, desfalecidos, alquebrados, que se contrapõem, em alguns quadros, à despreocupação e prazer impressos nos rostos e gestos dos que na cena desempenham o papel de torturadores indiferentes ao que se passa, ou na gestualidade dos golpes que imprimem aos corpos dos prisioneiros submetidos à barbárie. As figuras que Andreato elege, as cores fortes mobilizadas, a perspectiva "realista" da representação concorrem para acentuar a denúncia da degradação a que são submetidos os sujeitos sob tortura, tema que atravessa todos os contos ali reunidos. Pela explosão cromática, ganham a dimensão passional que atualiza a dor, o abandono, a morte.

Fig. 1

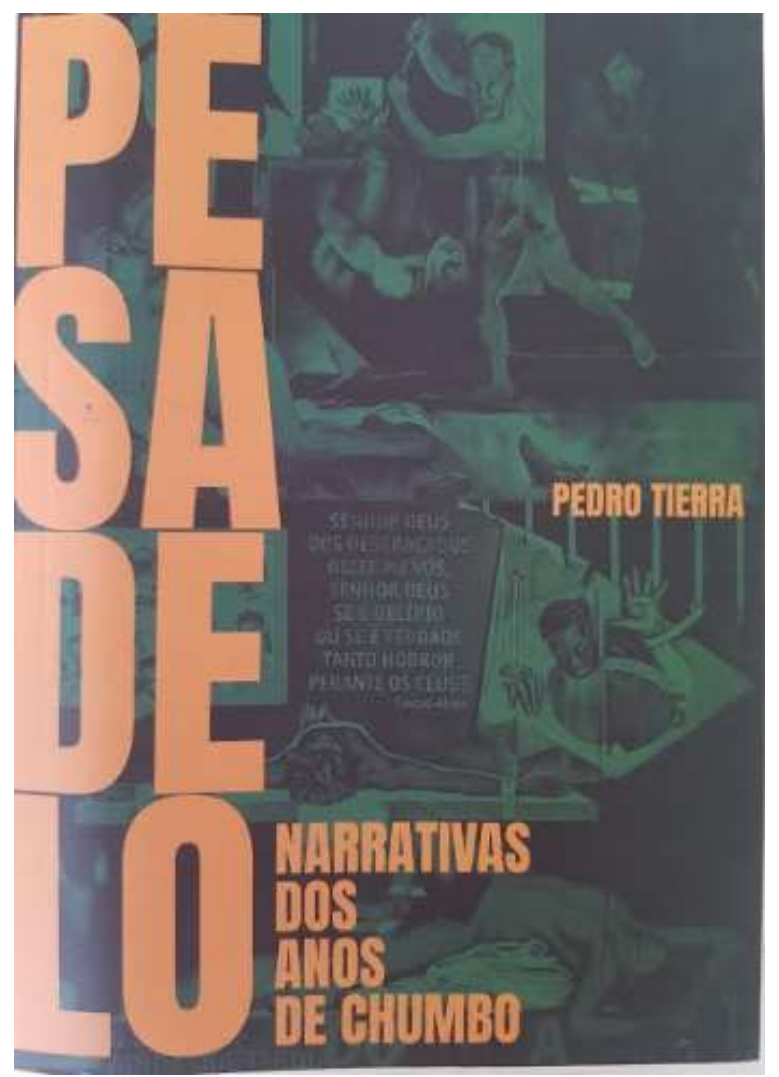

Foto da capa de Pesadelo... (TIERRA, 2019)
Fig. 2

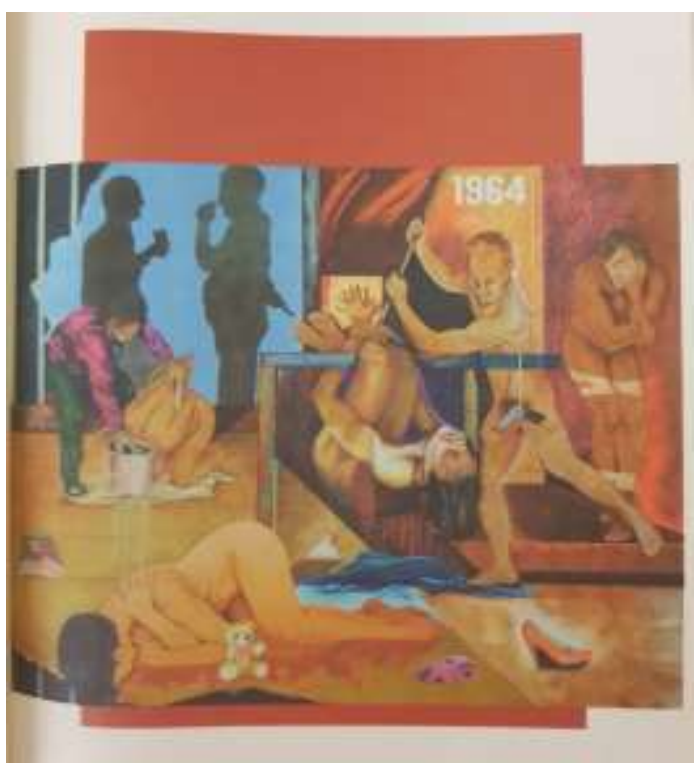

Print de ilustração de Andreato (TIERRA, 2019, p. 13)

\footnotetext{
${ }^{11} \mathrm{O}$ termo naif remete a uma arte de traços considerados "primitivos", "ingênuos", alicerçados na representação figurativa. Pensamos aqui nessa classificação inusual sobretudo pelo uso excessivo das cores e pelo traçado que visa a produzir efeito de realidade, com efeitos passionais.
} 
Compreende-se como figuras "todo conteúdo de um sistema de representação (visual, verbal ou outro) que tem um correspondente no plano da expressão do mundo natural, isto é, da percepção" (BERTRAND, 2003, p. 420). No gênero conto, a figuratividade tende a ser mais presente, adquirindo no caso de Tierra a função de concretizar os espaços, os objetos e os sujeitos que compõem o cenário do cárcere destinado aos considerados "subversivos". As imagens que compõem a ilustração servem, assim, para intensificar pelos recursos da visualidade o que se convoca do universo sensível pelas palavras, como na enumeração dos instrumentos postos ao alcance das mãos dos oficiais que se prestam à tarefa da tortura, seguindo o impulso e o comando: "Cassetetes, cavaletes, canos, capuzes, cadeiras do dragão, seringas, ampolas de pentotal sódico, máquinas à manivela próprias para ministrar choques, tudo à mão" (TIERRA, 2019, p. 143).

Como advertem Greimas e Courtés, ao confirmarem o apriorismo de que "todo sistema semiótico (literatura ou pintura, por exemplo) é uma 'representação' do mundo e comporta a iconicidade como dado primeiro", mesmo considerada a dimensão ficcional do literário,

seu caráter ficcional não se fundamenta em palavras - que se presumem que representem as coisas -, mas, em primeiro lugar, no arranjo das ações descritas de maneira que os lexemas inscritos no discurso não instalem aí figuras semióticas, mas “imagens do mundo” já acabadas. (GREIMAS; COURTÉS, 2008, p. 211-212)

Tierra traz as imagens desse universo prisional no contexto ditatorial, que exaspera práticas da violência do Estado, visando a destituir o sujeito de qualquer resistência, razão e esperança. As figuras que possibilitam ver, ouvir e sentir o que aquele que testemunha viveu se organizam por encadeamentos isotópicos de figuras que vão dar concretude ao instante terrível do encontro do corpo/sujeito com o sofrimento que sobre ele recai como punição. Como destinador supremo, o Estado não perdoa e tem nos oficiais e suboficiais os adjuvantes ideais, executando com prazer e/ou indiferença a sanção que ali se impõe:

Não guardava ideia de como viera parar nesta cela: um retângulo frio. Dois metros e meio por um e vinte. Completamente nua. Sem colchão. Com uma privada turca ao fundo. Primeiro dia. E o recomeço... O capuz verde-oliva. A sala escura. A sinfonia $\mathrm{n}^{\mathrm{o}} 2$ de Sibelius, o dínamo, os jacarés presos, nas orelhas, nos testículos, entre os dentes. Gosto de vidro quebrado a cada descarga elétrica. A jornada vertiginosa, sob a luz cega dos refletores. Circular. Suspensa. Interminável. (TIERRA, 2019, p. 34)

Conforme reiteram os editores na orelha inicial do volume, trata-se de uma obra de ficção, mas os "personagens são arrancados da vida compartilhada por ele [Tierra] em diferentes presídios". Além disso, os relatos dramáticos desfazem desde a advertência inicial a certeza de sua objetividade e precisão. No conto As mãos, por exemplo, o narrador traz o que seria fala de um militante do PCdoB no Araguaia capturado pelos militares, pondo em questão se de fato ouviu o relato que transcreve e se de fato o que ali se diz foi vivido ou apenas se 
mostra como efeito do delírio produzido na violência da prisão: "Talvez tenha ouvido esse relato da boca de um sobrevivente, dentro da cela três do quinto presídio por onde passamos, alguns anos depois, quando o delírio já havia devorado de sua mente os reflexos do inóspito território da realidade em que algum dia se moveu" (TIERRA, 2019, p. 127).

Testemunha-se, assim, não para atestar que as coisas aconteceram com a precisão com que são narradas, mas para confirmar que as coisas aconteceram e é preciso narrar, dar forma pela linguagem ao que ainda afeta ao sujeito, este que não pode esquecer, que não quer que o esquecimento lance seu manto, apagando os rastros.

\subsection{A resistência}

São distintos os espaços que servem ao cárcere, por isso também distintos os sujeitos que se fazem personagens a partir dos encontros que se dão com o narrador nas celas compartilhadas durante os anos de prisão: jovens e velhos "comunistas", oriundos de diferentes frentes de luta na história de um país que se escreve pela cartilha da desigualdade. Selecionamos aqui um dos contos para analisar do ponto de vista desses atores da resistência, encarcerados e submetidos à tortura, confinados provisoriamente num mesmo espaço.

Sem levar em conta que o que se narra é real ou ficcional, temos o encontro entre o narrador e o líder da luta dos posseiros da região de Trombas e Formoso, José Porfírio, a quem o conto O leitor do livro do Apocalipse é dedicado. José Porfirio de Souza (1912 - ?), natural de Pedro Afonso (hoje pertencente ao território do Tocantins) foi o primeiro deputado de origem camponesa no Brasil, eleito pela coligação PTB-PSB, em 1962, cassado em 1964. Sua liderança emerge nos anos 1940-50, quando defende os posseiros da grilagem em Goiás, conseguindo apoio da opinião pública e de estudantes goianos. Em 64, refugia-se no Maranhão, onde será encontrado apenas em 1973. Trabalhando ali na terra com familiares, ocupava-se também da alfabetização das crianças na região. Liberto da prisão meses depois, será um dos desaparecidos da ditadura. Com pouca escolaridade, "lia corretamente e escrevia com certo desembaraço", "lia tudo que lhe caía nas mãos, fosse o almanaque Capivarol ou a Constituição de 1937" (ABREU, 2002, p. 80).

Tierra apresenta na primeira linha o personagem como leitor de um único livro, a Bíblia, na versão distribuída pela igreja católica no interior do país:

\footnotetext{
Um livro que narra as intermináveis atribulações de um povo de pastores e pescadores, oprimido e opressor, desterrado e invasor de terras alheias. Um registro composto como um mosaico de fábulas, redesenhadas a cada geração, para alimentar na seguinte a primitiva noção de povo escolhido entre todos os povos. O povo eleito de Yaveh. (TIERRA, 2019, p. 71)
} 
Tierra vai estabelecer os pontos de contato entre as narrativas bíblicas de errância do povo judeu e a luta dos camponeses sem-terra no Brasil. Seguindo a promessa de um Eldorado nas terras mais ao norte do país, camponeses migrariam de diversas localidades para a ocupação de terras devolutas em Goiás, ameaçados depois por grileiros e lideranças políticas locais, quando as terras férteis passariam a ser mais valorizadas pela construção de uma rodovia federal. Considerando essa proximidade de narrativas, o narrador pensa que, em vez do livro do Apocalipse, o fascínio de Porfirio poderia voltar-se para o Êxodo:

Para quem palmilhara ásperos caminhos na vida, intuí que sua preferência recaísse sobre o Livro do Êxodo. Faria mais sentido. Guardaria nexo com a condição de condutor de uma comunidade de posseiros despojados de tudo, mesmo de uma escritura que servisse de escudo legal, para protegê-los naquela obscura luta contra usurpadores, nos vastos boqueirões de Trombas e Formoso, no Brasil Central. (TIERRA, 2019, p. 72)

A narrativa segue atravessada pelas citações do Apocalipse, que Porfírio recitava de memória, e no qual emerge um Deus vingativo, a punir a pecadora Babilônia, num gesto de sanção final, uma vez que “A misericórdia de Deus não tem limites, assim como não tem limites a sua ira" (TIERRA, 2019, p. 78). Enumera uma série de sujeitos propensos a serem arrebatados pelo texto que lhes produziria "alheamento", como sob efeito de uma "febre malsã": loucos, místicos, profetas, adivinhos, rejeitados, professorinhas do interior, virgens defloradas, amargos, poetas, mercenários, vagabundos, assassinos arrependidos, pastores de arrabalde, numa confusa e heterogênea mistura. Essa mistura entre a luta pela terra e a religiosidade de matriz popular vai fazer com que reconheça em Porfírio a encarnação de um novo Antônio Conselheiro, evidenciando a circularidade das narrativas em nossa história: "Quase cem anos depois de Canudos, a espantosa miséria dos sertões do Brasil prossegue inalterada, produzindo seu Messias para redimir multidões dos deserdados da terra...” (TIERRA, 2019, p. 74).

Sobre o fundo da continuidade que define a concentração da terra nas mãos de grileiros, gente que "morde com os dentes do governo" (TIERRA, 2019, p. 80), a resistência dos camponeses é a ruptura, ainda que precária e violentamente combatida. É ela que ecoa outros sentidos, desestabilizando a regularidade da concentração de terras e exploração dos trabalhadores. Para a resistência, a religiosidade opera para confirmar um Deus atento aos mais pobres, aos deserdados, num exercício de apropriação da leitura do livro sagrado como também da vida. Sem romper propriamente com a "programação" (LANDOWSKI, 2014), com a regularidade da sucessão contínua de um estado de coisas que se naturaliza por efeito da reprodução, a insurreição momentaneamente a desestabiliza. Em termos semióticos, teríamos o gesto intencional de introdução de uma "escapatória” que, deslocada de sua implicação no 
campo estético tal como a elabora Greimas (2002), incorporaria aqui a "resistência" que se constrói no campo político.

Não se sabe o paradeiro de Porfírio, desaparecido como muitos outros sujeitos por obra das forças da repressão. Ao final do capítulo, porém, o narrador, que parece inicialmente desdenhar do atravessamento do discurso bíblico pelo combatente dos sertões, acena para possibilidade de uma escuta mais atenta a sua perspectiva mística, considerando que possa ter optado por desparecer no mundo, como forma de escapar do braço opressor: "Quando sair daqui ninguém nunca mais saberá de mim. Conheço lugares que nem Jesus Cristo com os doze apóstolos pisou. Vou virar uma sombra. Uma sombra não se prende” (TIERRA, 2019, p. 82). Assistindo ao filme 2001: uma Odisseia no Espaço, reconhece na nave a imagem trazida pelo livro de Ezequiel e evocada por Porfírio nas suas referências ao Apocalipse. A cena o que o leva a sentir o misto de ameaça e de esperança.

\subsection{Programação: a roda que faz girar a tortura}

Há evidentemente muitos aspectos que demandam análise nos contos de Tierra, mas selecionamos os que podem ser compreendidos pelo regime de programação (LANDOWSKI, 2014; 2019), uma vez que pretendemos relacioná-lo às figuras e à temática da tortura dos presos políticos, que ganham centralidade ao longo do livro.

A programação corresponde a um dos regimes de interação, pressupondo que os sentidos, na perspectiva da sociossemiótica, emergem das relações sensíveis e inteligíveis estabelecidas entre sujeitos (intersubjetivas) e entre sujeitos e objetos (interobjetivas). Tendo em vista uma gradação que implica a menor ou maior previsibilidade que regula essas interações, a programação se situa no extremo do mais previsível e, por isso mesmo, implicando menos riscos, menos incidência do aleatório, com a confirmação da continuidade e da regularidade. No extremo oposto, acentuando o risco máximo dado pela introdução do imprevisível, encontra-se o acidente ${ }^{12}$.

Conforme Landowski, a programação corresponde mais de perto a "um processo articulado em termos de interobjetividade e de exterioridade", que reduz o actante a um "operador": "operar consiste em atuar a partir de fora (tipicamente, por meio de uma força) sobre a localização, a forma, a composição ou o estado de algum objeto" (LANDOWSKI, 2014, p. 22). Assim, para que operemos sobre os objetos, para que eles atendam aos objetivos que

\footnotetext{
${ }^{12}$ As distinções e aproximações entre os conceitos de acidente, trazido pela sociossemiótica de Eric Landowski e de acontecimento, pela semiótica tensiva de Claude Zilberberg, são exploradas por Jacques Fontanille (2016).
} 
definiram sua produção, é necessário que funcionem conforme o que está previsto, seguindo um dado algoritmo ou engrenagem que define sua constituição, sua ação.

Landowski mais adiante, porém, ressalta que a programação pode ser considerada também quando as práticas intersubjetivas se fundam nos princípios de regularidade extrema, como se dá com as sociedades de bases autoritárias.

\begin{abstract}
Mas ela pode também subjazer a um modo de organização social e política de tipo tecnocrático, no que tange às relações entre as pessoas. Dado que esses dois aspectos podem muito bem seguir de mãos dadas, quanto melhor se conseguir conjugá-los, mais se aproximará de um regime de segurança perfeita, sem acidentes nem desvios de qualquer tipo. Sua aliança culmina na organização de sociedades totalitárias de tipo burocrático, espécies de máquinas humanas a serviço da máquina de produção. (LANDOWSKI, 2014, p. 32)
\end{abstract}

Landowski exemplifica o conceito com o filme Metrópolis, de Fritz Lang, no qual os sujeitos são de tal modo controlados e alienados, tão bem reduzidos ao estatuto de meros executores, que apenas se limitam a atender às necessidades de uma máquina. Semelhante imagem podemos encontrar em Tempos Modernos, de Charlie Chaplin, com a repetição de ações na linha de montagem de uma fábrica, ou em Admirável mundo novo, de Aldous Huxley, com os papéis temáticos devidamente estabilizados para os sujeitos numa espécie de sistema produtivo baseado em castas.

A primeira parte do conto Ossos do Rio Verde é denominada por Tierra como A máquina se move. Ali o escritor relaciona uma série de sujeitos, seguindo a cadeia hierárquica responsável pelo funcionamento da máquina da tortura, associada aos muitos objetos dispostos à mão devidamente enumerados. Todas as peças ali se encaixam para o funcionamento devidamente programado, para o sucesso de uma prática sem risco que atende ao objetivo de "moer carne" ou de transformar sujeitos em resíduos. Seus operadores são aqueles que cumprem ordens, o que supostamente os aliviaria de dever produzir qualquer sentido para o que fazem, assim como assumir suas consequências. Essa indiferença com que operam é reiterada pelas ilustrações, que trazem os torturadores em comportamentos displicentes com relação ao que se sucede na cena principal: corpos desfalecidos, atravessados por intrincada teia de apetrechos que servem à produção da dor do outro, o "inimigo".

Cada uma delas isolada se move sem ter noção exata do objetivo. Obedecer mecanicamente ao impulso, ao comando: cumpre. Carcereiros, guardas, interrogadores mobilizados mais cedo, cada um traz de casa misturados na bagagem os ódios miúdos, fantasmas, invejas, desejos, desenganos, cumplicidades, suas escassas convicções políticas. E um sentido profissional canino. (TIERRA, 2019, p, 142) 
A enumeração das figuras dos carcereiros, guardas, interrogadores atesta não propriamente a presença de sujeitos, mas uma cadeia de operadores encerrados em seus papéis temáticos. Ainda que carreguem de casa suas paixões e convicções, o que sinalizaria para sua humanidade, estas se prestam a melhor atender ao "sentido profissional canino" com o qual se dispõem a executar o comando. São, ao lado dos cassetetes, cavaletes, canos, capuzes, seringas, cadeiras do dragão etc., peças na engrenagem do sistema que programa sujeitos e objetos, separando os que acionam a manivela e os que serão deformados, triturados, aniquilados. A máquina produz finalmente a submissão desejada e o sofrimento agora se esconde nas entranhas do que resta do sujeito.

Cada vez que passa, encolhe. Volta menor, gasto, roído pelo cupim das palavras proferidas sob o impulso do medo... O medo da dor. Já quase não há interrogatórios. E quando há, são breves. Sem pancadaria ou gritos. E ele regressa curvado, sem fitar ninguém. Exceto os buracos que cavou dentro de si mesmo. (TIERRA, 2019, p. 151)

A máquina cumpre sua destinação de moer corpos e esfarrapar as almas.

Há, porém, uma outra máquina que a princípio pode se fazer invisível. É a que define, sob o giro de uma manivela de maior envergadura, a circularidade de nossa triste história.

\section{Considerações finais}

Na análise do texto de Tierra (2019), buscamos levantar algumas questões para o debate em torno da literatura de testemunho a partir dos fundamentos da teoria semiótica, principalmente aquela que se concentra na noção do acontecimento (ZILBERBERG, 2011). Compreendida a partir de produções que denunciam grandes e impactantes eventos, como os vinculados aos genocídios, a literatura de testemunho pode ser pensada como a literatura do acontecimento, o que traz à tona a (im)possibilidade de narrá-lo na intensidade da sua experiência. Nós a encontramos tanto os relatos dos que escreveram durante o intervalo de seu processo, na "continuação da parada" (TATIT, 1997), tal como se deu com o próprio Tierra (2009) no trabalho com a poesia ou com o judeu Gradowski aqui citado (COQUIO, 2003), quanto no que se torna possível mediante a memória "parada da parada" (TATIT, 1997), como é o caso da prosa de Tierra (2019) e de um dos principais precursores do gênero, Primo Levi (1988).

Ressaltamos, porém, que esse gênero pode se voltar ainda para a produção de sentido quando se opera sobre a regularidade da programação, da rotina, da previsibilidade, pela imersão de descontinuidades que concorrem para a busca de ruptura com um dado estado de coisas. Ali se encontrariam as produções de Jesus (2014) e de Fernandes Júnior (2020), o 
Torero. Greimas (2002) denominaria a insistência na produção do sentido do ponto de vista estético e estésico frente ao contínuo como escapatórias, enquanto a traduzimos para o campo da luta cotidiana como resistência, estratégia que marca a intencionalidade de romper com coerções e determinações sociais. Resistimos não apenas na arte, no prazer estético, mas também pela ação política, pelas mãos do trabalho.

Se tanto o acontecimento quanto a programação operam para a impossibilidade do sentido, no primeiro caso pelo excedente e no segundo pela vacuidade, a literatura de testemunho opera para a resistência no sentido, para sua legibilidade ou, ao menos, sua enunciação.

Num momento em que somos chamados a novamente lutar pela democracia, confirmamos que assumimos aqui os riscos de uma semiótica implicada, com um olhar teórico expressamente comprometido, tal como se dá pela convocação de Landowski (2001). Pegamos para o embate as nossas armas.

\section{REFERÊNCIAS}

ABREU, Sebastião. Do Zé Porfirio ao MST: a luta pela terra em Goiás. Brasília: André Quicé, 2002.

ACHÚGAR, Hugo. Historias paralelas/ejemplares: la historia y la voz del otro. In:

BEVERLY, John; ACHÚGAR, Hugo (org.). La voz del outro: testimonio, subalternidad y verdad narrativa. 2 ed. Lima-Berkeley: Latinoamericana Editores; Guatemala: Universidad Rafael Landívar, 2002, p. 61-82.

BERTRAND, Denis. Caminhos da semiótica literária. Bauru, SP: EDUSC, 2003.

COQUIO, Catherine. L'emergence de une "littérature" de non écrivains: les témoignages de catastrophes historiques. Revue d'Histoire Littéraire de la France, n. 2, v. 103, p. 343-362, 2003.

EVARISTO, Conceição. Becos da memória. 3 ed. Rio de Janeiro: Pallas, 2007.

FIGUEIREDO, Cesar A. Sagrillo. Literatura de testemunho: a literatura das catástrofes. Revista EntreLetras, Araguaína, v. 11, n. 1, p. 7-27, 2020.

FONTANILLE, Jacques. Um diálogo imaginário entre Claude Zilberberg e Eric Landowski: em torno do acontecimento, da álea e do acidente. In: MENDES, Conrado M.; LARA, Glaucia M. P. (Org.). Em torno do acontecimento: uma homenagem a Claude Zilberberg. São Paulo: Appris, 2016, p. $17-34$.

JESUS, Carolina M. de. Quarto de despejo: diário de uma favelada. 10 ed. São Paulo: Ática, 2014.

GREIMAS, Algirdas J.; COURTÉS, Jacques. Dicionário de semiótica. São Paulo: Contexto, 2008. 
GUINZBURG, Jaime. Linguagem e trauma na escrita do testemunho. In: SALGUEIRO,

Wilberth Clayton (Org.). O testemunho na literatura: representações de genocídios, ditaduras e outras violências. Vitória: Editora da UFES, 2011, p. 19-32.

LANDOWSKI, Eric. Antes da interação, a ligação. Trad. Luiza Helena Oliveira da Silva, Murilo Scoz, Yvana Fechine, Eric Landowski. São Paulo: Centro de Pesquisas

Sociossemióticas, 2019.

LANDOWSKI, Eric. Interações arriscadas. Trad. Luiza Helena Oliveira da Silva. São Paulo: Centro de Pesquisas Sociossemióticas; Estação das Letras e Cores, 2014.

LANDOWSKI, Eric. O olhar comprometido. Galaxia, n. 2, p. 17-56, 2001.

LEVI, Primo. É isto um homem? Trad. Luigi Del Re. Rio de Janeiro: Rocco, 1988.

MARCO, Valéria de. A literatura de testemunho e a violência de Estado. Revista Lua Nova, n. 62, p. 45-68, 2004.

SELIGMANN-SILVA, Márcio Orlando. Literatura de testemunho: os limites entre a construção e a ficção. Revista Letras, Santa Maria, RS, v. 16, p. 9 - 37, 1988.

SILVA, Luiza Helena O. da. Memórias da guerrilha: acontecimento e história. In: MENDES, Conrado M.; LARA, Glaucia M. P. (Org.). Em torno do acontecimento: uma homenagem a Claude Zilberberg. Curitiba: Appris, 2016, p. 141-162.

TATIT, Luiz. Musicando a semiótica. São Paulo: Annablume, 1997.

TESTA, Eliane C.; MARINHO, Paulo A. Falando de poesia: entrevista com o poeta Pedro Tierra. EntreLetras, Araguaína, v. 9, n. 3, p. 363-371, 2018.

TIERRA, Pedro. Pesadelo: narrativas dos anos de chumbo. São Paulo: Autonomia Literária; Fundação Perseu Abramo, 2019.

TIERRA, Pedro. Poemas do povo da noite. São Paulo: Fundação Perseu Abramo; Publisher Brasil, 2009.

FERNANDES JUNIOR, José Roberto Torero. Quarenteninhas 3. Disponível em: https://www.facebook.com/joserobertotorero Acesso em 22 mai. 2020.

ZILBERBERG, Claude. Elementos de semiótica tensiva. Trad. Ivã Lopes, Luiz Tatit, Waldir Beividas. São Paulo: Ateliê Editorial, 2011.

Recebido em 04/06/2020. Aceito em 16/08/2020. 